\title{
Seroprevalence of Hepatitis A among Different Age Groups in Sakarya and Review of The Literature
}

\author{
Farklı Yaș Gruplarında Hepatit A Seroprevalansı; Sakarya Verileri ve Literatür Derlemesi
}

\author{
Mehmet KÖROĞLU1,2, Tayfur DEMIRAY2, Hüseyin AGAH TERZ|2, Mustafa ALTINDIŞ1,2 \\ 1Sakarya University Faculty of Medicine, Department of Clinical Microbiology, Sakarya, Turkey \\ 2Sakarya Training and Research Hospital, Clinic of Clinical Microbiology, Sakarya, Turkey
}

\begin{abstract}
Objectives: The aim of this study was to investigate the seroprevalence of hepatitis A virus (HAV) infection in all age groups in Sakarya province and to review previously presented data about HAV seroprevalence in Turkey.

Materials and Methods: We retrospectively evaluated the records of patients who were tested for IgG anti-HAV and Igm anti-HAV for diagnostic and screening purposes between of 01.01.2012 and 31.12.2013. Anti-HAV antibodies in serum samples were analyzed with chemiluminescence microparticle immunoassay (CMI) method (Architect i2000, Abbott). Values below $1 \mathrm{~s} / \mathrm{co}$ were accepted as negative and values $\geq 1 \mathrm{~s} / \mathrm{co}$ were considered positive.

Results: IgG anti-HAV positivity was determined in $1498(74.7 \%)$ people out of 2003 for the two-year screening period. Positivity rates were found as $29.7 \%, 43.4 \%$, $57.1 \%, 84.8 \%, 96.8 \%, 99 \%$, and $99.3 \%$ in the age groups $0-10,11-20,21-30,31-40$, 41-50, 51-60 and 61-92, respectively. IgM anti-HAV positivity was detected in 75 (4.44\%) of 1693 people. IgM anti-HAV positivity rates according to age groups $0-10$, $11-20,21-30,31-40,41-50,51-60$, and $61-92$ years were $13.2 \%, 13.7 \%, 6.3 \%, 1 \%$, $0 \%, 0 \%$, and $0.6 \%$, respectively.

Conclusion: Our study provides information about the serological status of HAV in Sakarya. Knowledge of the seroprevalence of hepatitis A virus will be guiding for establishing appropriate preventive measures and creation of vaccination programs. Besides the use of vaccines, sanitation activities, creation of healthy water sources, and improving infrastructure systems will make significant contribution toward reducing the incidence of HAV infection. The data obtained from this and similar studies will provide the opportunity to examine and compare the results of the routine HAV vaccination in the forthcoming years. (Viral Hepatitis Journal 2014; 20(3): 110-114)
\end{abstract}

Key words: Hepatitis A, anti-HAV, IgG anti-HAV, IgM anti-HAV, seroprevalence, hepatitis A vaccine

Conflict of interest: The authors reported no conflict of interest related to this article.
ÖZET

Amaç: Bu çalışmada Sakarya ilinde tüm yaş grupları için Hepatit A virus (HAV) enfeksiyonunun seroprevalansının araştıııması ve ülkemize ait daha önce yayınlanmış verilerin derlenmesi amaçlanmıştır.

Gereç ve Yöntemler: Çalışmamızda 01.01.2012 ile 31.12.2013tarihleri arasında tanı ve tarama amaçı anti-HAV IgG ve anti-HAV IgM testi istenen hastalara ait kayıtlar retrospektif olarak incelenmiştir. Anti-HAV antikorlarının varlığı kemiluminesens mikropartikül immunoassay (CMIA) yöntemi ile (Architect i2000, Abbott) çalışılmıştrr. Bir s/co altındaki değerlere sahip numuneler negatif ve $\geq 1 \mathrm{~s} / \mathrm{co}$ değerlerine sahip örnekler pozitif olarak değerlendirilmiş̧tir.

Bulgular: Iki ylllkk sürede tarama yapılan 2,003 kişiden 1,498'inde $(\% 74,7)$ anti-HAV IgG pozitifliği saptanmıştır. Sıfır-10 yaş grubunda $\% 29,7,11-20$ yaş grubunda $\% 43,4$, $21-30$ yaş grubunda $\% 57,1,31-40$ yaş grubunda $\% 84,8,41-50$ yaş grubunda $\% 96,8$, $51-60$ yaş grubunda $\% 99$ ve $61-92$ yaş grubunda $\% 99,3$ oranında anti-HAV IgG pozitif bulunmuştur. Anti-HAV IgM pozitifliği, çalıșma kapsamındaki 1,693 kişiden 75'inde $(\% 4,44)$ saptanmıştır. Yaş gruplarına göre anti-HAV IgM pozitifliği ise $0-10$ yaş $\% 12,1,11-20$ yaş $\% 15,9,21-30$ yaş $\% 6,9,31-40$ yaş $\% 1,7,41-50$ yaş $\% 0,5,51-60$ yaş $\% 0,6$ ve 60 yaş üstünde $\% 1,2$ olarak saptanmıştır.

Sonuç: Çalışma, Sakarya ilinin HAV yönünden serolojik durumu hakkında bilgi vermektedir. Hepatit A virüsünün prevalansının bilinmesi hastalık için uygun koruyucu önlemlerin alınabilmesinde ve aşı programlarının oluşturulmasında yol gösterici olacaktır. Aşı kullanımının yanında, sanitasyon çalışmaları, sağ|ılı su kaynaklarının ulaşılabilir hale getirilmesi ve kanalizasyon-alt yapı çalışmalarına ağırlık verilmesi de HAV enfeksiyonları sıkı̆̆ını azaltacaktır. Bu ve benzeri çalışmalardan elde edilen veriler, ilerleyen yıllarda rutin HAV aşı uygulamasının sonuçlarını incelemek amacıyla yapılacak araştırmalara katkı ve mukayese imkanı sağlayacaktır. (Viral Hepatit Dergisi 2014; 20(3): 110-114)

Anahtar kelimeler: Hepatit A, anti-HAV, anti-HAV IgG, anti-HAV IgM, seroprevalans, hepatit A aşıS

Çıkar çatışması: Yazarlar bu makale ile ilgili olarak herhangi bir çıkar çatışmas bildirmemişlerdir. 


\section{Introduction}

Hepatitis A virus (HAV) infection that is characterized by primary inflammation of the liver causes a self-limited, nonchronic disease (1). The fecal-oral route is the primary mode of transmission since a high amount of virus is excreted by an infected person. Also, person-to-person contact, ingestion of contaminated food and water, and spread between people in the same house are other ways of transmission (2). $70 \%$ of HAV infections are asymptomatic and not accompanied by jaundice in children under five years of age, however, in adults and older children, infection is symptomatic with jaundice occurring in $70 \%$ of patients. Less than $1 \%$ of patients develop fulminant hepatitis. Fulminant disease due to hepatitis $A$ is more likely to resolve spontaneously than fulminant diseases of other viral etiologies (3).

$\operatorname{lgG}$ anti-HAV and IgM antibodies are investigated for the diagnosis. The virus has 4 genotypes capable of infecting humans and has only one serotype. IgG anti-HAV, which appears early in the course of infection, provides lifetime protection against the disease. Determination of IgG anti-HAV is a method commonly used in prevalence studies. The aim of this study was to determine the distribution of IgG anti-HAV and $\lg \mathrm{M}$ seropositivity rates in different age groups.

\section{Materials and Methods}

We retrospectively evaluated the records of patients who were tested for IgG anti-HAV and IgM anti-HAV seropositivity for diagnostic and screening purposes in Sakarya University Training and Research Hospital between of 01.01.2012 and 31.12.2013. Blood samples from patients were separated by centrifugation and anti-HAV antibodies in serum samples were analyzed with chemiluminescence microparticle immunoassay (CMIA) method (Architect i2000, Abbott, USA). Repeating samples were excluded from the study. S/Co values of less than 1 were accepted as negative; and s/co values of more than 1 were considered positive according to manufacturer's instructions.

For statistical evaluation, SPSS 21.0 program (IBM inc, Chicago, USA) was used and one-way ANOVA test was performed. A $p$ value of less than 0.05 was considered statistically significant.

\section{Results}

In the two-year screening period, out of 2.003, 1498 (74.7\%) subjects were found to be positive for IgG anti-HAV. Of the positive patients, 39\% were female $(n=782)$ and $35.7 \%$ were male. Positivity rates are presented in Table 1 . In this study, IgG anti-HAV positivity rate was observed as more than $96 \%$ in the groups over 41 years of age.

IgG anti HAV seropositivity in 0-10, 11-20 and 21-30 age groups were significantly lower compared to 31-40, 41-50, $51-60$ and $61-92$ age groups ( $p<0.001)$. There was no statistically significant difference between the other age groups.
IgM anti-HAV positivity was detected in 75 (4.44\%) of 1693 people. IgM anti-HAV positivity rates in the age groups $0-10,11-20,21-30,31-40,41-50,51-60$, and 61-92 years were $13.2 \%, 13.7 \%, 6.3 \%, 1 \%, 0 \%, 0 \%$, and $0.6 \%$, respectively. The highest IgM anti-HAV positivity was seen in the 11-20 years age group (Table 2). IgM anti-HAV seropositivity rates in 0-10, $11-20$ and 21-30 age groups were significantly higher compared to $31-40,41-50,51-60$ and $61-92$ age groups $(p<0.001)$. There was no statistically significant difference between the other age groups.

\section{Discussion}

HAV infection is detected in all over the world. It is common in developing countries and like other enteric virus infections, is one of the typical diseases of childhood (4). The infection usually takes place during childhood period in developing countries, due to fecal-oral transmission in consequence of insufficient infrastructure and sewage services, and contaminated water supplies. In general, in countries with higher socioeconomic levels, HAV infections are encountered in older age groups. It has been demonstrated that, the reduction in the number of cases in these countries may be attributed to improved hygiene and sanitation conditions in addition to routine vaccination $(3,5)$.

Turkey is in a middle endemic region according to the epidemiological data of HAV infections. The seroprevalence of HAV infection differs among various regions of the country. Ceyhan et al. detected HAV seroprevalence in the central and the western regions of the country as moderate, whereas HAV seroprevalence was high in the eastern and southern parts $(6,7)$. Noteworthy, it has been shown that seropositivity rates in different regions, sometimes within the same province and even within different residential areas could differ $(8,9)$. Data about the distribution of HAV seropositivity, collected from several publications conducted in Turkey according to age groups, between the years of 2004-2012, are given in Table 3.

It is clear that hepatitis A virus is still endemic and widespread in our country as stated in many previously conducted studies. Western regions, where socioeconomic levels higher and more developed in terms of hygiene and sanitation conditions, it is observed that the age distribution shifts toward adolescents and young adulthoods (10). In this regard, an adult group who are prone to HAV infection has been reported $(11,12)$. With advancing age, the risk of HAV infection as well as likelihood of complicated clinical course increases (4). According to the Centers for Disease Control and Prevention, USA (CDC), the overall case-fatality ratio of $\mathrm{HAV}$ infections is $3 \%$, this ratio is $1.8 \%$ in adults older than 50 years of age (13). In this study, in concordance with the previous ones, seropositivity of HAV gradually increases with age (Table 1, 2). Similar data have been reported in different areas of the world. In a study conducted in Korea, it was stated that the incidence of HAV infection in the age group over 30 years has increased from $15.2 \%$ in the years between 1995 and 1999, to $28.4 \%$ in the years between 2000 and 2005 (14). The incidence rate was almost doubled, 
thus, this situation was interpreted as a population in the adult age group was formed, who were susceptible to HAV infection and this specific group should be protected. These findings emphasize the importance of researches including of all age groups.

In studies performed in different regions of Turkey, the seroprevalence in children has been reported to vary between $35 \%$ and $80 \%$ (15). Çopur et al. reported that the prevalence of $\operatorname{lgG}$ anti-HAV IgG among children was $29.5 \%$ (16). In our study, the rate in children was found to be $29.7 \%$. As stated in recent studies performed on pediatric age group, seropositivity rates have started to decline (Table 1,2). These findings may be considered as the result of improvements in hygiene and sanitation conditions, as well as routine immunization.

Routine infant hepatitis $A$ vaccination for hepatitis $A$ has been taken to the vaccination schedules in our country by the

\begin{tabular}{|c|c|c|c|c|c|}
\hline \multirow{2}{*}{ Age Group } & \multicolumn{4}{|c|}{ Anti-Hepatitis A Virus IgG Positive } & \multirow{2}{*}{$\begin{array}{l}\text { Total } \\
\text { Positivity (\%) }\end{array}$} \\
\hline & Male & $\%$ & Female & $\%$ & \\
\hline $0-10(n=128)$ & 26 & 20.3 & 12 & 9.4 & 29.7 \\
\hline $11-20(n=265)$ & 54 & 20.4 & 61 & 23 & 43.4 \\
\hline $21-30(n=445)$ & 117 & 26.3 & 137 & 30.8 & 57.1 \\
\hline $31-40(n=400)$ & 156 & 39 & 183 & 45.8 & 84.8 \\
\hline $41-50(n=283)$ & 127 & 44.9 & 147 & 51.9 & 96.8 \\
\hline $51-60(n=200)$ & 106 & 53 & 92 & 46 & 99 \\
\hline $61-92(n=282)$ & 130 & 46.1 & 150 & 53.2 & 99.3 \\
\hline Total $(n=2003)$ & 716 & 35.7 & 782 & 39 & 74.7 \\
\hline
\end{tabular}

year 2012. In addition, HAV seronegative health care workers who work in high-risk departments are being vaccinated. Hepatitis A immunization is determined by factors such as age and anti-HAV seroprevalence (10). Children are very contagious and may spread the virus to individuals in all age groups. Therefore, vaccination in this group will contribute to immunity in the whole society and the protection of unvaccinated persons (17). By the routine administration of hepatitis $A$ vaccine in the United States, the incidence of HAV infection has dropped from 30021 cases annually in 1997 to 8795 cases in 2002 (18).

Studies performed on adult population in different years and regions in our country demonstrated different results (Table 3). In a study conducted in the Çanakkale Providence, the prevalence rate was $78.2 \%$ in $0-91$ age group (19). A multicenter study, determined the prevalence as $74 \%$ (20). In the literature, HAV positivity in adult patients has been reported

\begin{tabular}{|c|c|c|c|c|c|}
\hline \multirow{2}{*}{ Age Group } & \multicolumn{4}{|c|}{ Anti-Hepatitis A Virus IgM Positive } & \multirow{2}{*}{$\begin{array}{l}\text { Total } \\
\text { Positivity } \\
\text { (\%) }\end{array}$} \\
\hline & Male & $\%$ & Female & $\%$ & \\
\hline $0-10(n=159)$ & 15 & 9.4 & 6 & 3.8 & 13.2 \\
\hline $11-20(n=196)$ & 20 & 10.2 & 7 & 3.5 & 13.7 \\
\hline $21-30(n=344)$ & 13 & 3.7 & 9 & 2.6 & 6.3 \\
\hline $31-40(n=289)$ & 1 & 0.3 & 2 & 0.7 & 1 \\
\hline $41-50(n=193)$ & 0 & 0 & 0 & 0 & 0 \\
\hline $51-60(n=169)$ & 0 & 0 & 0 & 0 & 0 \\
\hline $61-92(n=343)$ & 0 & 0 & 2 & 0.6 & 0.6 \\
\hline Total $(n=1693)$ & 49 & 2.9 & 26 & 1.54 & 4.44 \\
\hline
\end{tabular}

Table 3. Distribution of hepatitis A virus seropositivity in different parts of the Turkey

\begin{tabular}{|c|c|c|c|c|c|}
\hline Study & Year & Providence/City & Age & Number & $\begin{array}{l}\text { Anti-Hepatitis A Virus } \\
\text { IgG Seropositivity (\%) }\end{array}$ \\
\hline Arabacı, (19) & 2009 & Çanakkale & $0-91$ & 1363 & 78.8 \\
\hline Turker, (22) & 2004-2009 & Multicenter & $15-81$ & 709 & 96.8 \\
\hline Çetinkol, (27) & 2011 & Ünye & $0-50$ & 728 & 57.9 \\
\hline Tosun, (24) & 2011 & Multicenter & $<20,>71$ & 2107 & 91.1 \\
\hline Altuntaş, (25) & $2006-2011$ & Haseki & $27-49$ & 221 & 91 \\
\hline Karakaş, (26) & 2012 & Ankara & $17-43$ & 392 & 47.4 \\
\hline Ertürk, (4) & 2012 & Rize & $17-70$ & 1112 & 75 \\
\hline This Study & 2014 & Sakarya & $0-92$ & 2003 & 74.7 \\
\hline Tosun, (20) & 2007-2009 & Multicenter & $1-80$ & 3715 & 74 \\
\hline Tekay, (11) & 2004-2005 & Hakkari & $0-14$ & 416 & 68 \\
\hline Aslan, (28) & 2008-2009 & Gaziantep & $0-18$ & 15.246 & 61 \\
\hline Arvas, (29) & 2011 & Iğdır & $0-18$ & 990 & 18 \\
\hline Okur, (30) & 2011 & Van & $0-18$ & 3409 & 69.9 \\
\hline
\end{tabular}


to be between $88.8 \%$ and $100 \%$ (21). Recent studies reported seropositivity rates varying between $75 \%$ and $96.8 \%$ in adults (people older than 15 years of age) $(4,22)$. In our study, we found that the seropositivity rate was $87.4 \%$ in individuals between 21 and 92 years of age. In the age group 21-30, the rate was $57.1 \%$ and the highest rates range from $84.8 \%$ to $99.3 \%$ in $30-92$ age groups (Table 1). There was a significant increase in seropositivity rate after 30 years of age. These data showed that the age distribution shifted toward advanced ages. We determined nearly the same results with a recent study conducted by Alicl et al. in 2013. It was stated that after the fourth decade of life, seropositivity increased over $90 \%$ (23).

Hepatitis A infection is the problem of developing countries, especially when infrastructure and sewage services are inadequate and water sources are contaminated. Domestic migrations and foreign migrations due to war are so intense even in our city, that enough attention should be paid to avoid outbreaks especially for the other diseases transmitted by fecal-oral route together with hepatitis A. Improvements in socioeconomic and hygienic conditions decrease the HAV infection incidence. However the importance of active immunization is increasing not only in the adult population but also in high-risk groups due to higher morbidity and mortality at later ages (20). In areas with a high proportion of susceptible adult population, appropriate vaccination programs should be implemented at least in the high-risk groups, such as healthcare professionals, sewage workers, soldiers, workers in the food industry, people with chronic hepatitis B and C, drug addicts, and etc.

An important and remarkable determination should be mentioned that there are differences in many studies conducted in Turkey in aspect of the age groups. Since age groups were not homologous, effective comparisons and evaluations within the age groups between data from different studies cannot be established. Standardization of age groups in prevalence researches will provide efficient use of the data.

Our study provides information about the serological status of HAV in Sakarya. Knowledge of the seroprevalence of hepatitis A virus will be guiding for establishing appropriate preventive measures and creation of vaccination programs. Besides the use of vaccines, sanitation activities, creation of healthy water sources, improving infrastructure systems will make significant contribution toward reducing the incidence of HAV infection. The data obtained in this and similar studies will provide an opportunity to examine the effectiveness of routine HAV vaccination.

\section{References}

1. Curry MP, Chopra S. Acute Viral Hepatitis. In: Mandell GL, Bennett JE, Dolin R (eds.), Principles and Practice of Infectious Diseases. 6 st ed. Churchill Livingstone, Philadelphia; 2005. p.1426-1440.

2. Hadler SC. Global impact of hepatitis A virus infection: changing patterns. In: Hollinger FB, Lemon SM, Margolis HS (eds.), Viral hepatitis and liver disease. Baltimore: Williams and Wilkins; 1991. p.14-20.
3. Nothdurft $\mathrm{DH}$. Hepatitis $\mathrm{A}$ vaccines. Expert review of vaccines. 2008; 7(5): 535-545.

4. Erturk A, Copur Cicek A, Cure E, Akdoğan RA, Ozturk Ç. Rize Ilinde Erişkin Yaş Gruplarında Hepatit A Seroprevalansı. Viral Hepatit Dergisi. 2013; 19(2): 85-88.

5. Türker K, Balcı E, Batı S, Hasçuhadar M, Savaş E. Ülkemizde Hepatit A Enfeksiyonunun Değişen Epidemiyolojisi. Türk Mikrobiyol Cem Derg. 2011; 41(4): 143-148.

6. Uzun O. Viral Hepatitler: Epidemiyoloji. In: Uzun O, Unal S (eds.), Guncel Bilgiler Işığında Infeksiyon Hastalıkları. Cilt II. Ankara: Bilimsel Tıp Yayınevi; 2002. p.561-566.

7. Ceyhan M, Yıldırım I, Kurt N, Uysal G, Dikici B, Ecevit C. Differences in hepatitis A seroprevalance among geographical regions in Turkey: a need for regional vaccination recommendations. Journal of Viral Hepatitis. 2008; 15(Suppl. 2): 69-72.

8. Mıstık R. Türkiye'de viral hepatit epidemiyolojisi - Yayınların irdelenmesi. In: Tabak F, Balık I, Tekeli E (eds), Viral Hepatit. Istanbul: Viral Hepatitle Savaşım Derneği Yayını, Istanbul Medikal Yayıncılık; 2007. p.9-50

9. Tosun S. Hepatit A virüs enfeksiyonu. Tabak F, Tosun S (eds), Viral Hepatit. Istanbul: Viral Hepatitle Savaşım Derneği Yayını, Istanbul Medikal Yayıncılık; 2013. p.215-46.

10. Tosun S. Viral Hepatitlerin Ülkemizdeki Değişen Epidemiyolojisi. ANKEM Derg. 2013; 27(Suppl 2): 128-134.

11. Payne L, Coulombier D. Hepatitis A in the European Union: respondig to challenges related to new epidemiological patterns. Euro Surveill. 2009; 22; 14(3). pii19101.

12. Sağlık Bakanlığı. Hepatit $A$ vaka ve ölüm sayıları, morbidite ve mortalite hızları, 1990-2005. 2010 [http://www.saglik.gov.tr]. 25.08.2014

13. http://wwwnc.cdc.gov/travel/yellowbook/2014/chapter3-infectious-diseases-related-to-travel/hepatitis-a \#362. 25.08.2014.

14. Song HJ, Kim TH, Song JH, Oh HJ, Ryu KH, Yeom HJ, Kim SE, Jung HK, Shim KN, Jung SA, Yoo K, Moon IH, Chung KW. Emerging need for vaccination against hepatitis $A$ virus in patients with chronic liver disease in Korea. J Korean Med Sci. 2007; 22(2): 218-222.

15. Tekay F. Hakkari Devlet Hastanesine Başvuran 0-14 Yaş Grubu Cocuklarda Hepatit A Sıklığı. Dicle Tıp Dergisi. 2006; 33(4): 245247.

16. Copur Cicek A, Ozkasap S, Dereci S, Şahin K, Dilek AR, Gundoğdu Ulusan DZ, Dilek RA, Ertürk A. Rize Illinde Cocuk Hastalarda Hepatit A, B ve C Seroprevalansı. Viral Hepatit Dergisi. 2012; 18(3): 102-106.

17. Yoldas O, Bulut A, Altindis M. The Current Approach of Hepatitis A Infections. Viral Hepatitis J. 2012; 18(3): 81-86.

18. Ince B. Adana il merkezinde 1999'dan 2009'a hepatit A seroprevalansında epidemiyolojik shift (kayma). Uzmanlık Tezi. Adana: Çukurova Üniversitesi Tıp Fakültesi, Çocuk Sağlığı ve Hastalıkları Anabilim Dalı,2010.

19. Arabacı F, Oldacay M. The seroprevalance of Hepatitis $A$ in Different Age Groups and Hepatitis A Incidence in Acute Hepatitis Cases in The Canakkale Province. J Pediatr Inf. 2009; 3: $58-61$.

20. Tosun S, Ayaz H, Deveci S, Aksu S. Cocuk ve Erişkinlerde Hepatit A Virusu ile Karşılaşma Durumunun Değerlendirilmesi. X.Ulusal Viral Hepatit Kongre Kitabı. Antalya, 2010; 121.

21. Aygen B: Hepatit A Virusu. Ed: Willke Topcu A, Soyletir G, Doğanay M. Infeksiyon Hastalıkları ve Mikrobiyolojisi Cilt II., Nobel Tıp Kitabevleri, İstanbul 2008;1871-1882.

22. Turker K, Oğan CH, Iskender G, Erbay C, Balcı E, Hascuhadar M, et al. Gunumuz Turkiye'sinde Hepatit A Kronik Viral Hepatitlerde Gercek Bir Sorun mudur? X.Ulusal Viral Hepatit Kongre Kitabı. Antalya, 2010; 167. 
23. Alıcı Ö, Ağalar C, Yazıcılar HA. Hepatitis A Seroprevelance in Patients who admitted to Training and Research Hospital in Istanbul. Viral Hepatitis J. 2013; 19(3): 110-114.

24. Tosun S, Yıldız O, Tekinkoruk S, Celen MK, Yılmaz G, Karabay $\mathrm{O}$, et al. Kronik HBV ve HCV Olgularının HAV ile Karşılaşma Durumlarını Yeterince Değerlendiriyor muyuz? XI. Ulusal Viral Hepatit Kongre Kitabı. Antalya, 2012; 80-81.

25. Altuntaş AO, Kumbasar KH, Korkusuz R, Ataoğlu HE, Nazlıcan O. HIV/AIDS Hastalarında HAV IgG Seroprevalansı. XI. Ulusal Viral Hepatit Kongre Kitabı. Antalya, 2012; 84-85.

26. Karakaş A, Coşkun O, Mert G, Gul HC, Avcı IY, Eyigun CP. Hepatit A Seroprevalansında Yedi Yılda Ne Değişti?. XI. Ulusal Viral Hepatit Kongre Kitabı. Antalya, 2012; 52.
27. Cetinkol Y, Yıldırım AA. Unye Devlet Hastanesine Başvuran Hastalarda Hepatit A Seroprevalansı. Kocatepe Tıp Derg. 2011; 12: $18-22$.

28. Aslan S, Değirmenci S, Yiş R, Çıtak Ç. Gaziantep Çocuk Hastanesi Iki Yıllık Hepatit A Belirteçlerinin Değerlendirilmesi. X. Ulusal Viral Hepatit Kongre Kitabı. Antalya, 01-04 Nisan 2010; 117.

29. Arvas G, Kaya B, Berktaş M. The seroprevalance of Acute Hepatitis A in 0-18 Age Group Children who Applied to Iğdır State Hospital. J Pediatr Inf. 2011; 5: 129-131.

30. Okur M, Erbey F, Acar MN, Güven A, Kaya A. Van lli ve Çevresinde 0-18 Yaşları Arasındaki Çocuklarda Hepatit A Seropozitifliği. Düzce Tıp Derg. 2011; 13(2): 6-9. 